Georgia State University

ScholarWorks @ Georgia State University

$3-1-2020$

\title{
Linguistically Responsive Teaching in pre-service teacher education: A review of the literature through the lens of cultural- historical activity theory
}

\author{
Ana T. Solano-Campos \\ Georgia State University, asolanocampos@gsu.edu \\ Megan Hopkins \\ University of California -San Diego, mbhopkins@ucsd.edu \\ Laura Quaynor \\ The Johns Hopkins University, Iquaynor@jhu.edu
}

Follow this and additional works at: https://scholarworks.gsu.edu/ece_facpub

Part of the Pre-Elementary, Early Childhood, Kindergarten Teacher Education Commons

\section{Recommended Citation}

Solano-Campos, Ana T.; Hopkins, Megan; and Quaynor, Laura, "Linguistically Responsive Teaching in preservice teacher education: A review of the literature through the lens of cultural-historical activity theory" (2020). Early Childhood and Elementary Education Faculty Publications. 11.

https://scholarworks.gsu.edu/ece_facpub/11

This Article is brought to you for free and open access by the Early Childhood and Elementary Education Department at ScholarWorks @ Georgia State University. It has been accepted for inclusion in Early Childhood and Elementary Education Faculty Publications by an authorized administrator of ScholarWorks @ Georgia State University. For more information, please contact scholarworks@gsu.edu. 


\title{
Author Accepted Manuscript
}

Solano-Campos, A., Hopkins, M., \& Quaynor, L. (2020). Linguistically Responsive Teaching in pre-service teacher education: A review of the literature through the lens of cultural-historical activity theory. Journal of Teacher Education, 1-15.

\section{Linguistically Responsive Teaching in Pre-Service Teacher Education:}

\section{A Review of the Literature through the Lens of Cultural-Historical Activity Theory}

\author{
Ana Solano Campos \\ Megan Hopkins \\ Laura Quaynor
}

In an era marked by demographic change, the education of bi/multilingual students identified as English Learners (ELs) is a critical issue for schools across the United States (Lucas \& Villegas, 2011). While EL is the most-often used term to refer to students who are learning English, we use the term multilingual learners (MLLs) to highlight their linguistic resources, and to maintain an asset-based orientation. The number of MLLs in US schools is the highest in over a century (Wright, Boun, \& García, 2015), yet most general education teachers have not received much, if any, preparation to meet their diverse linguistic, cultural, academic, and socioemotional needs (Ballantyne, Sanderman, \& Levy, 2008; Coady, Harper, \& de Jong, 2016; Gebhard, 2010). 
Teachers' lack of preparation can negatively affect MLLs' educational trajectories (Master, Loeb, Whitney, \& Wyckoff, 2016). Further, teachers may hold deficit-oriented beliefs that temper their expectations for MLL learning and thus the instructional practices they use (Pettit, 2011; Rodriguez, Manner, \& Darcy, 2010). Acknowledging the need to better prepare general education teachers, several states have implemented MLL-related requirements in the last two decades. University-based teacher education programs have thus begun to develop MLL-focused coursework with Pre-Service Teachers (PSTs; Samson \& Collins, 2012).

To inform this ongoing work, we conducted a systematic literature review to investigate how teacher educators attend to components of a Linguistically Responsive Teaching (LRT) framework for MLL education (Lucas \& Villegas, 2011). The LRT framework was selected as it synthesizes theory and empirical research from multicultural education and diverse fields of linguistics into distinct pedagogical skills and orientations needed by educators of MLLs, specifically focused on preparing novices. Then, we used cultural-historical activity theory (CHAT; Engeström, 2001, 2007) to examine how teacher education has taken up LRT as part of a system designed to support PST learning. We employed CHAT because PST coursework on MLL education often exists as a separate class (Cochran-Smith \& Villegas, 2015), a structure that tends to reify the notion that MLLs are not an integral part of teaching in a general education classroom. The question guiding our review was: How are dimensions of the LRT framework taken up in teacher education activity systems to support PST learning about MLLs? 


\section{Preparing Teachers to Work with Multilingual Learners}

It has long been assumed that MLLs must develop English proficiency before learning academic content (Canagarajah, 2015). In the last two decades, a more robust knowledge base has emerged in conversation with the field of bilingual education (Hakuta, 1986; Thomas \& Collier, 1997) that supports the integration of language and content (García, 2009; Janzen, 2008; Nieto \& Bode, 2012). This scholarship illuminates the challenges and possibilities associated with teaching content in English to MLLs (Cummins, 2000, 2008), and facilitates the development of teaching methods (Chamot \& O’Malley, 1994; Echeverria, Vogt, \& Short, 2003). Most recently, scholars have investigated approaches for teaching content in multiple languages to MLLs (García et al., 2017).

Scholars conceptualize the knowledge and skills necessary for general education teachers to facilitate content-based language instruction, such as: linguistic knowledge for teaching (Reeves, 2004), pedagogical language knowledge (Bunch, 2013; Galguera, 2011), and disciplinary linguistic knowledge (Turkan, de Oliveira, Lee, \& Phelps, 2014). Some of these foreground teachers' theoretical expertise in second language acquisition and bilingualism, while others highlight the need for teachers to acquire pedagogical skills to address MLLs' language needs across the content areas (DiCerbo et al., 2014). Prior research syntheses similarly emphasize pedagogical skills and linguistic aspects of teaching content, for example by using Systemic Functional Linguistics (SFL; Halliday, 1993, 1994; Schleppegrell, 2004; Schleppegrell \& Achugar, 2003; Schleppegrell, Achugar, \& Oteíza, 2004). SFL "provide[s] teachers with tools to analyze the language features central to academic work in different content areas" (Bunch, 
2013, p. 209), and attends to language functions for specific purposes, contexts, and disciplines.

Less attention has been paid to how PSTs are prepared to support sociocultural and sociolinguistic aspects (Teemant \& Hausman, 2013), despite evidence that the social context influences MLL education (Ovando, 2003). Classroom-based research reveals the importance of affirming MLLs' home languages and funds of knowledge, or the "historically accumulated and culturally developed bodies of knowledge and skills" embedded in families' linguistic and cultural practices (Moll, Amanti, Neff, \& Gonzalez, 1992, p.134). Scholars point to the academic, linguistic, and social benefits of designing instruction that connects content with MLLs' everyday practices (Gutierrez, Baquedano-Lopez, \& Tejada, 1999; Orellana \& Reynolds, 2008; Risko \& Walker-Dalhouse, 2007). Nonetheless, the extent to which teachers facilitate these practices depends on the sociopolitical context. In the wake of federal accountability and state English-only policies, many schools turned toward sheltered English instruction and away from bi/multilingual approaches (Menken, 2010). In these contexts, MLLs benefit when their teachers understand the social context and serve as advocates for culturally and linguistically responsive policies and practices (de Oliveira \& Athanases, 2007; Martin \& Strom, 2016).

\section{Linguistically Responsive Teaching and Cultural-Historical Activity Theory}

We used LRT to investigate how teacher educators attend to linguistic and sociocultural approaches as they prepare PSTs to work with MLLs in general education classrooms. Then, we used CHAT to conceptualize PST education as an activity system, allowing us to investigate how dimensions of the LRT framework were taken up across different teacher education systems. We expand on this dual theoretical framework below. 


\section{Linguistically Responsive Teaching}

Lucas and Villegas' (2013) LRT framework synthesizes theories from teacher education and linguistics to outline two areas in need of attention in MLL teacher preparation. First, orientations aligns with sociocultural approaches and encompasses three dimensions: 1) sociolinguistic consciousness; 2) an appreciation for language diversity; and 3) a propensity to advocate for MLLs (see Table 1). The first dimension reflects an understanding that language, culture, and identity are interconnected, while the second speaks to the importance of respecting MLLs' home languages and enacting accompanying actions. The third dimension highlights the need to take action to improve MLLs' opportunities and to promote asset-oriented approaches beyond the classroom, including family engagement.

Second, pedagogical knowledge and skills attends to linguistic approaches across four dimensions: 1) strategies for learning about students' backgrounds; 2) understanding principles of second language learning; 3) identifying content-specific language demands; and 4) strategies for scaffolding instruction. Whereas the first dimension focuses on learning about MLLs' experiences, the second highlights five principles that teachers should understand and apply: the difference between conversational and academic language (Cummins, 2008; Gibbons, 2002); the importance of comprehensible input (Krashen, 2003); the need for interaction embedded in communicative activities (Walqui, 2007); the transfer of skills from the first language to the second (Thomas \& Collier, 2002); and the importance of students' affective state (Krashen, 2003). Then, the third dimension focuses on teachers' ability to identify language demands of classroom tasks and particular disciplines. Finally, the fourth dimension centers on developing a 
repertoire of strategies for scaffolding MLL instruction.

\section{Cultural-Historical Activity Theory}

CHAT (Engeström, 2008; Leontiev, 1981) provided a lens for understanding teacher education as a system in which dimensions of the LRT framework are addressed (Ellis, Edwards, \& Smagorinsky, 2010). We used Engenström's (1987, 1993) third generation activity theory, which builds on Vygostky's (1978) sociocultural theory of mind and on Leontiev's (1981) collective motivated activity. Engenström's theory focuses on activity systems as the unit of analysis to understand how human activity is collectively mediated around a shared goal, and how expansive learning and transformation occurs within and between activity systems. The basic principles of third generation activity theory are reflected in the basic activity triangle in which two triangles represent activity systems connected by a shared object, or goal. Each activity system encompasses: (a) subjects, or individuals engaged in the activity; (b) rules, or formal and informal guidelines for how to interact; (c) community, or the social group with which subjects identify; (d) division of labor, or how tasks are shared; and (e) mediating tools or artifacts that contribute to engagement (Yamagata-Lynch, 2010).

Researchers applying this framework to teacher education examine how interactions, conceptual and pragmatic tools, and activities lead to opportunities for PST learning (Ellis et al., 2010; Jahreie \& Ottesen, 2010; McDonald, 2005; Turner \& Drake, 2016). Liu and Fisher (2010), for example, use CHAT to understand conflicts between two teacher education activity systems, one focused on traditional pedagogical practices, and the other focused on liberal pedagogical practices. They examine the boundary crossing processes that occur between these systems to 
generate new knowledge or practices (i.e., expansive learning). Similarly, Jahreie and Ottesen (2010) explore how tools (e.g., lesson plans) and PST interactions transform activity systems to reconstruct the object of learning. We build on this scholarship and examine how the LRT framework is taken up in teacher education activity systems focused on MLL-related learning.

\section{Methods}

\section{Sample}

Our review included 64 peer-reviewed journal articles published between 2001-2017 on the pre-service preparation of general education teachers of MLLs in the United States. We used 2001 as the starting year for two reasons. First, 2001 was the first year that any state legislated MLL-related requirements for general education teachers (Ballantyne et al., 2008). Second, with the passage of No Child Left Behind in 2002, the EL subgroup became an explicit policy focus; since then, there has been evident growth in the number of studies documenting the preparation of PSTs for work with MLLs. We first conducted an electronic database search in ERIC, using the terms "pre-service teacher" or "teacher candidate" or "teacher education" alongside "English language learner" or "English learner" or "emergent bilingual," as these are the most frequently used terms for MLLs in the literature. We also systematically combed recent issues (2015-2017) of relevant journals (e.g., Journal of Teacher Education, Teaching and Teacher Education, Teacher Education Quarterly, TESOL Journal) to locate articles not yet listed in ERIC.

We screened a total of 220 articles, of which we immediately excluded 69 because they either were not focused on MLLs or were conducted outside the United States. We downloaded or otherwise acquired the remaining 151 articles and skimmed the full text to identify those that: 
were peer-reviewed, focused on the preparation of PSTs pursuing general education licensure, and reported findings from an empirical study. A total of 64 articles met these criteria.

Overall, all 64 studies focused on PSTs attending US universities. While the majority of studies (56 or $88 \%$ of the sample) focused on PSTs pursuing elementary or secondary credentials, eight studies included general education PSTs pursuing ESL or bilingual endorsements. We opted to include these eight studies because they focused on PSTs planning to work with MLLs in general education classrooms. Of the studies that specified geographic locations ( $\mathrm{n}=52), 40 \%$ were conducted in the West, $33 \%$ in the South, $12 \%$ in the Midwest, and $15 \%$ in the Northeast (according to US Census Bureau (n.d.) Regions and Divisions).

\section{Analysis}

We uploaded PDF versions of each article into NVivo 10 for analysis, which occurred in two phases, one that applied the LRT framework and one that focused on components of CHAT.

LRT framework. First, we coded articles according to dimensions of the LRT framework (see Table 1). We first read seven randomly selected articles (about 10\% of the sample) and met to discuss whether and how the articles addressed LRT dimensions. We discussed which of the three orientations dimensions, and which of the four pedagogical knowledge and skills dimensions, were considered by researchers in either their approaches for working with PSTs or their analysis of PSTs' learning. Based on this initial review, we identified two areas that were consistently explored but were not identified explicitly by Lucas and Villegas (2011). One area related to the orientations dimension, and how teacher educators facilitated PSTs' reflection on and interrogation of preexisting beliefs about MLLs. The other 
area fell under pedagogical knowledge and skills, and focused on how PSTs learned to develop personal relationships with MLLs and their families. Though these areas are related to existing LRT dimensions, we opted to add these two codes given their predominance in the literature, and that they were treated separately from other dimensions.

After agreeing on our code list, each researcher individually coded the seven articles; then, we ran a coding comparison query and met as a team to identify and discuss any discrepancies. We continued this process with these seven articles, meeting weekly for a period of two months, until we established inter-rater reliability with at least $90 \%$ agreement. To facilitate our discussions, each researcher kept a coding log that detailed why each code was applied or not applied. We also collaboratively created a codebook (Macqueen, McLellan-Lemal, Bartholow, \& Milstein, 2007) and revised our code definitions during each meeting, as well as identified examples and non-examples of each code. These tools helped us address any persistent disagreements, which tended to revolve around whether or not a code should be applied if the dimension was an unintentional outcome of the study. We collected a list of examples where this occurred and referred to our codebook to decide how to address it. Ultimately, we decided to include these instances, as it was often difficult to ascertain intentionality (or lack thereof).

After coming to consensus on the LRT codes, we divided the remaining articles equally and coded them individually. Based on our coding, we sorted the sample into three groups based on the LRT framework: (1) articles focusing primarily on orientations, (2) those focusing on pedagogical knowledge and skills, and (3) those addressing aspects of orientations and pedagogical knowledge and skills about equally (see Table 2). We considered an article focused 
primarily on orientations or pedagogical knowledge and skills if more than three-quarters of the codes applied were from that dimension. For example, for an article had 12 codes applied, if at least 8 of those codes were from the orientations category, we considered it part of that group. Then, articles in the third group were those that had about equal numbers of codes across orientations and pedagogical knowledge and skills. To triangulate sorting conducted by hand, we input the LRT codes into Stata 13 and conducted a principal component analysis to display the pattern of similarity of the codes, which similarly clustered articles into these three groups.

CHAT. We considered each group to be an activity system, where teacher educators and PSTs engaged in collective activity organized around the goal of either orientations, pedagogical knowledge and skills, or both. Our coding in this phase sought to identify the community in which activities took place, the division of labor and rules, as well as the predominant mediating tools and artifacts. We each read the articles in one group, and separately developed a list of codes applying the CHAT framework to each group of studies.

After weekly discussions of these codes over a one-month period, we gained consensus on a code list to apply across all three groups. For example, we developed codes for mediating tools and artifacts based on the resources teacher educators used such as reflective journals, lesson plans, and fieldwork (i.e., experiences in schools or communities). We also developed a list of codes related to the community in which each study took place, and the teaching methods employed (i.e., division of labor). We then created a content-analytic summary matrix for each group (Miles \& Huberman, 1994). Each matrix listed codes for each study according to components of the activity system, which enabled sorting within each component and allowed us 
to identify themes and generate assertions.

\section{Activity Systems in Linguistically Responsive Teacher Preparation for MLLs}

We present our findings by providing a description of the three activity systems (see Figure 1). These systems shared a common object: to support the provision of linguistically responsive education for MLLs. Nonetheless, each system addressed distinct LRT dimensions via different CHAT components, which we detail below.

\section{Focus on Beliefs: The Orientations Activity System}

The majority of studies (36 studies, or 56\% of the sample) focused on PST's orientations. Half of these studies described the development of PSTs' sociolinguistic consciousness, while others emphasized a value for language diversity ( 9 studies), an inclination to advocate (6 studies), or a value for relationship building with MLLs (3 studies). Although the development of PSTs' sociolinguistic consciousness was often accompanied by attention to PSTs' value for language diversity (Athanases, Banes, \& Wong, 2015; Kayi-Aydar, 2015) or inclination to advocate (Major \& Perreault, 2004; Santamaria, Santamaria, \& Fletcher, 2009), only two studies (Hale, 2008; Hutchinson, 2013) incorporated all three dimensions.

CHAT components of the orientations activity system. The shared object, or goal, of studies focused on PST orientations was to facilitate change in PSTs' beliefs about MLLs through self-reflection. Activities in these systems were typically conceptualized around critical theory, social justice, and identity development frameworks. For example, Colon-Muñiz and colleagues (2010) employed a study abroad program to facilitate PSTs' “catalytic transformation capacity" (p. 62), or the ability to use changed beliefs to drive subsequent teaching practices. 
Similarly, Bollin (2008) described PSTs' service learning experiences with Mexican immigrant children and their families as having the potential to "predispose the prospective teachers to be sensitive to the needs of other ethnically diverse populations" (p. 178).

Teacher educators and PSTs were the primary subjects engaged in activities in this system, and the university classroom was the focal community, or "social group with which the subject identifie[d] while participating in the activity" (Yagamata-Lynch, 2010, p. 23), even when school- or community-based fieldwork was included. Typically, expectations for changing PSTs' beliefs were placed on a single course. Additionally, the majority of studies used qualitative analysis of PSTs' written reflections to investigate their developing abilities to reflect on and/or critique beliefs about MLLs. As a result, course assignments were the primary tools/artifacts used to examine PST learning. Rules and division of labor were led by teacher educators, who structured PSTs' learning experiences to encourage both the discovery and interrogation of their beliefs about MLLs.

These experiences consisted primarily of what Block (2002) calls critical experiences, “[p]eriods of time during which prolonged contact with an L2 and a new and different cultural setting causes irreversible destabilization of the individual's sense of self' (p. 4). This definition is useful to illustrate the purpose of the mediating spaces and devices used by teacher educators in the orientations system: to make possible opportunities for cognitive dissonance (i.e., instances in which an individual is confronted with new information that contradicts her beliefs or values; Adcock, 2012). These opportunities occurred as part of PSTs' university-based coursework, such as cultural and/or language immersion and language simulations (e.g., Alfaro, 
2008; Zhang \& Pelttari, 2014), or engagement with or observation of MLLs in classroom or afterschool settings (e.g., Dresser, 2007; Fitts \& Gross, 2012).

Most teacher educators in the orientations system reported that critical experiences positively influenced PSTs' beliefs about MLLs and pointed to the benefits of connecting theory and practice via concurrent university- and school-based experiences (McDonald, 2005). Nearly all of the studies in the orientations system relied on PSTs' reported perceptions of their learning and development, but did not describe how these ideas were put into practice or demonstrated in their work with MLLs. Studies reporting little to no change in PSTs' beliefs noted several obstacles: PSTs' feelings of frustration, superficial understandings of cultural and/or linguistic difference, and low levels of multicultural sensitivity and persistence (Hutchinson, 2013; Nichols \& Soe, 2013; Pappamihiel, 2004; Wade, Fauske, \& Thompson, 2008). Generally, these obstacles were described as challenges for PSTs as individuals, rather than as features of the course.

Studies in this system suggested that PSTs must develop particular beliefs about MLLs before enacting specific pedagogical practices. Given that critical experiences served as starting points for PSTs' learning, they can also be understood as boundary zones (Max, 2010; Konkola et al., 2004) where teacher educators facilitated entry into various settings to trigger a change in perspective or awareness about MLLs. Then, course assignments functioned as layered tools that helped PSTs negotiate tensions between their beliefs, observations, and course content.

\section{Focus on Method: The Pedagogical Knowledge and Skills System}

Fewer studies (12, or 19\% of the sample) focused primarily on the development of PSTs' pedagogical knowledge and skills (PKS). Among those, the majority (10 out of 12) focused on 
scaffolding instruction, and the remaining two focused primarily on PSTs' understanding and ability to apply second language learning principles. Three studies also focused on the development of PSTs' knowledge of the language demands of classroom tasks, and four examined PSTs' acquisition of a repertoire of strategies for learning about MLLs' backgrounds. For example, Dong (2004) describes how teacher educators capitalized on "effective pedagogy in action" as teachers adjusted the language demands of classrooms tasks to facilitate PSTs' scaffolding of vocabulary instruction for MLLs. Similarly, Schall-Leckrone and McQuillan (2012) used SFL to support PSTs in deconstructing texts, identifying the academic language of historical analysis, and applying these tools to their design of scaffolded lessons. Whereas these two studies focused on lesson planning, others explored PSTs' enactment of scaffolding, for instance by drawing on MLLs' everyday experiences and visual literacy tools to facilitate connections to science content (Kelly-Jackson \& Delacruz, 2014), or by using authentic assessment data to inform instruction (Athanases Wahleithner, \& Bennett, 2013; Lyon, 2013).

CHAT components of the PKS activity system. The object of the PKS activity system was to improve PSTs' teaching practice through application of various instructional strategies. Although teacher educators in the PKS system also used critical experiences to facilitate PST learning, their main purpose was not to challenge PSTs' beliefs or assumptions, but to improve PSTs' knowledge of and effectiveness in using particular teaching techniques. Hence, the most frequently employed theoretical perspective was teacher development, with an emphasis on knowledge development (as opposed to identity development). Notably, no studies in the PKS system drew on critical or social justice perspectives. 
PSTs and teacher educators were the main subjects, or individuals engaged in the PKS activity system, yet participants in fieldwork settings also played a prominent role by taking part in "official" instructional activities, such as mentoring or student teaching. Moreover, whereas the primary community in the orientations system was the university classroom, school settings were the primary community in the majority of studies in the PKS system. Accordingly, the main tools for participation were school-based practica or field experiences involving MLLs (Bunten, 2010; Dong, 2004; Dresser, 2007; Kelly-Jackson \& Delacruz, 2014; Zainuddin \& Moore, 2004; Zhang \& Stephens, 2013). As in the orientations system, rules and division of labor in the PKS system were established by teacher educators, who in addition to facilitating discussion of course materials and field experiences, had an important role modeling or demonstrating strategies and supervising field experiences. PSTs, on the other hand, were tasked with implementing concepts rather than just observing or reflecting.

Most studies in the PKS system made broad references to increasing PSTs' awareness of or confidence in using strategies to teach subject area matter to MLLs; however, they did not describe in detail how this awareness was developed, or the particular types of scaffolding strategies learned. Moreover, though the majority of authors were also course instructors or supervisors, few unpacked PSTs' field experiences to identify which facets supported the development of particular knowledge and/or skills. Because the majority of studies relied on PSTs' self-reported knowledge and/or skills, it is unclear whether and how PSTs applied them with MLLs. Nonetheless, the studies in this group point to the value of school-based practicums for developing PKS for teaching MLLs. 


\section{Focus on Integration: Towards a Combination Activity System}

Sixteen studies ( $25 \%$ of the sample) integrated or balanced dimensions of both areas of the LRT framework. Half of these studies focused on self-reflection and examination of previously held beliefs about MLLs, in addition to developing PSTs' knowledge of scaffolding strategies and strategies for learning about MLLs. Typically, as PSTs engaged in tutoring or hands-on classroom activities through their involvement in a university course, they had opportunities to reflect on their beliefs and develop strategies for learning about MLLs' backgrounds and experiences. Then, the awareness they developed was built upon by teacher educators to introduce practical ways to make instruction accessible to MLLs.

One study illustrates particularly well the integration of orientations and PKS in the combination activity system. Grounded in a funds of knowledge approach, Amaro-Jimenez (2016) documented Participatory Action Research (PAR) in which PSTs engaged in a semesterlong home-school project called "Family Suitcases." PSTs wrote case studies with reflections about MLLs' familial and educational contexts, and used what they learned to design instructional activities and resources that were sent home with students. In addition to analyzing the work in their suitcases, the teacher educator, who was also the author of the study, analyzed PSTs' reflections on how to best fulfill MLLs' linguistic needs.

CHAT components of the combination activity system. In general, systems that integrated both orientations and PKS sought iterative, simultaneous engagement of PSTs with self-reflection and strategy implementation. Rather than relying on one or more components of a course to facilitate individual change, the object was to embed PSTs in classroom and institution- 
wide cultures in which instructional practice in the content areas was infused with asset-based perspectives. Overall, the teacher preparation contexts in this activity system used a variety of theoretical approaches, from social justice to teacher development, and considered a range of spaces from in-class experiences to off-site field experiences, to a full program sequence.

Teacher education contexts in this activity system typically included several communities across which PSTs interacted (e.g. university, school, home). This system not only promoted boundary-crossing across settings, but it also encouraged a "fusion of horizons" (Gadamer, 2012, as in McNess, Arthur \& Crossley, 2015, p. 305) which allowed PSTs to understand various social spaces in MLLs' lives and thus attend to different dimensions of the LRT framework in a unified way. Teacher educators and PSTs were the main subjects, and the rules and division of labor allowed teacher educators to engage PSTs in sustained, comprehensive immersion and involvement in the teaching of MLLs. The main tools used by teacher educators consisted of experiences and assignments that required PSTs to actively, consistently, and organically work with teachers, parents, and students.

Even though all studies in this group reported positive shifts in PSTs' development, only one used a comparison group to examine the effect of a particular intervention on PST learning. Walker-Dalhouse and colleagues (2009) compared self-reports between PSTs enrolled in a methods course that included a pen-pal program with refugee MLLs and PSTs enrolled in a section that did not include the pen-pal program. Although limited to self-reports, the researchers found that the course with the pen-pal experience was more effective than the other course in developing PSTs' knowledge of second language acquisition and scaffolding strategies. 
Overall, the studies in this activity system provide insights to inform a comprehensive approach for preparing PSTs to work with MLLs. Each study attended to between four and seven components of the LRT framework; thus, it may not be feasible for teacher educators to attend to all nine categories in just one experience or course. This finding is important, given that some states require the completion of only one course related to teaching MLLs, and other states have no specific requirements related to teaching MLLs for general education PSTs (Lopez et al., 2013). In addition, although many studies included diverse samples of PSTs, none explicitly explored the backgrounds or experiences of multilingual PSTs, or how their cultural and linguistic knowledge might shape their engagement with various LRT dimensions.

\section{Discussion}

Our review identified three activity systems illustrating how the LRT framework was taken up in teacher education. Drawing on our findings, we discuss the need for program-wide coherence in PST education and for comparative analyses to examine PST preparation across diverse policy contexts.

\section{Program-Wide Coherence in Teacher Preparation for Multilingual Learners}

For the most part, the activity systems we identified focused on PSTs' learning in just one or two courses in a given teacher education program. Studies that included multiple courses, or examined full programs, were retrospective and holistic, lacking detail related to how PSTs developed particular orientations or pedagogical knowledge and skills. It is thus unclear how different programmatic features (e.g., coursework, field experiences) might interact over time to support different LRT dimensions. Moreover, given that three-quarters of the studies we 
reviewed attended to either orientations or PKS, we know less about whether and how teacher education programs integrate these dimensions over time. Such integration may be particularly challenging given the distinct theoretical approaches employed. Whereas studies in the PKS system tended to draw on theories of cognition and knowledge development, studies in the orientations system drew on critical theory and social justice perspectives. This distinction may reveal a disjuncture between these systems and their mediating tools and activities, where a focus on technique and cognition, without attention to sociolinguistic awareness, may deflect from the ideological and systemic structures that perpetuate inequality for MLLs (Bartolomé, 1994). As Daniel (2014) suggests, if teacher educators wish to understand PST preparation focused on MLLs, it is critical to consider the activity system of the teacher education program as a whole (also see Athanases \& de Oliveira, 2007).

Importantly, whereas studies in the orientations system sometimes attended to PKS, albeit not in substantial ways, studies in the PKS system seldom drew concrete connections to sociocultural contexts. This is despite evidence indicating that one of the most important components of effective teaching for MLLs is a critical stance and the use of sociocultural practices (Teemant \& Hausman, 2013). In fact, scholars consistently argue that emphasizing methods alone is not enough to improve outcomes for MLLs, particularly when those methods are grounded in English-only approaches (Bartolomé, 1994; Crawford \& Adelman Reyes, 2015; Valenzuela, 1999). As our findings reveal, there is a burgeoning body of research that is beginning to integrate these aspects of a LRT framework. Nonetheless, more scholarship is needed to understand how to integrate sociocultural and sociopolitical aspects into PST 
preparation programs.

Programmatic studies of MLL teacher preparation should also attend to diversity within the PST population. It is only in very recent years that teacher education scholars have paid attention to how PSTs' experiences and backgrounds shape their learning and development related to teaching MLLs (Athanases, Banes, \& Wong, 2015; Eros, 2016; Miller, 2017). Yet the vast majority of studies in our review explored groups of PSTs without examining variation in the development of orientations or PKS by race/ethnicity, language background, or prior experience in linguistically and culturally diverse settings. Given that we know this kind of variation matters for MLL learning, we assume it is also important for PSTs' learning, and for developing activity systems that best facilitate their development. More research is needed to understand the diversity of PSTs' experiences within and between teacher education systems, and how they mediate activities in those systems.

\section{Comparative Analyses Across Policy Contexts}

The activity systems we described reside within the political context of their locale, their institution, their state, nation, and world. The studies reviewed did not provide much, if any, information related to the political contexts in which teacher preparation for MLLs occurred. As such, we have yet to understand how PSTs' opportunities to integrate and apply the skills in the LRT framework are restricted or supported in different states or school systems. For example, while structured English immersion (SEI) has been state policy in Arizona, South Carolina, and Massachusetts, there are requirements to provide bilingual education in Colorado, California, 
Texas, New York, and Illinois. At the same time, school districts vary in their implementation of quality instruction for MLLs, and PSTs' field experiences may shape their opportunities to develop linguistically responsive orientations or pedagogical knowledge and skills. While nearly all the articles we reviewed included a description of the study's location, few described the ways in which this location circumscribed educational possibilities. As such, there is a need to consider case studies as vertically positioned in national and local contexts (Vavrus \& Bartlett, 2017), and to compare and contrast teacher education programs to elucidate how these contexts interact with PST development. An activity system framework may be useful in this work.

Although states vary in their policies for MLLs, the studies we reviewed overwhelmingly focus on PST preparation in English-dominant environments. Given that most PSTs in the US are monolingual (Kibler \& Roman, 2013), this emphasis is not particularly surprising. Nonetheless, the lack of attention to bilingual orientations and strategies is striking, especially given growing interest in dual language education (Kim, Hutchinson, \& Winsler, 2015) and translanguaging (García et al, 2017). As many states offer increasing numbers of dual language programs, it is important to examine whether and how teachers will be prepared to support MLLs in these contexts. Moreover, since many programs prepare PSTs to teach MLLs who speak different languages, it is important for research and practice to attend to how MLLs' first language is used as a tool to support interactions within teacher education activity systems. Indeed, some emerging scholarship considers how language use among multilingual PSTs can be a source of linguistic content knowledge (Musanti \& Rodriguez, 2017).

\section{Limitations}


Our study, like all research, has limitations. Two of these limitations are discussed here. First, in the majority of studies reviewed, the researchers were also the teacher educators. Although this trend is common in teacher education research (Anderson \& Stillman, 2013), it may have introduced positive bias into the results reported. Indeed, the majority of studies highlighted positive shifts in PSTs' beliefs, knowledge, or skills; as such, the features of the teacher education systems we described may not be entirely representative of all such systems. Second, we may have interpreted the data presented in a given study differently than the researchers. For example, in Ahn's (2008) study of the effects of a service learning experience on PSTs' learning, one PST stated: "I saw the problem because not everybody supports bilingual education. So I realized that we have to fight for it. What I want to do after this is get more involved in bilingual education definitely. And when I get my degree I want to keep doing this.” Whereas the researcher captured this comment as "application of course theories," we coded this example as an inclination to advocate based on our theoretical lens.

\section{Conclusion}

Given that much teacher education scholarship has been critiqued for its lack of attention to theory (Anderson \& Stillman, 2013; Sleeter, 2014), our review connects the extant theoretical literature on PST preparation for MLLs to empirical teacher education research. We explicitly took up the LRT framework and examined how teacher education research operationalized it via different activity systems. Orientations-focused activity systems predominated, providing critical experiences for PSTs and opportunities for self-reflection aimed at changing beliefs. Yet as the field of PST preparation for MLLs grows, teacher education research and practice must 
incorporate features of systems focused on the pedagogical knowledge and skills dimension of the LRT framework. As teacher educators learn more about how to facilitate PSTs' development across LRT dimensions, we look forward to micro-studies of pedagogical techniques as well as macro-studies that embed techniques within and across courses, programs, and contexts. 


\section{References}

Adcock, A. (2012). Cognitive dissonance in the learning processes. In N. Seel (Ed). Encyclopedia of the sciences of learning (pp. 588-590). New York: Springer.

Adger, C. T., Snow, C. E., \& Christian, D. (Eds.) (2002). What teachers need to know about language. McHenry, IL: Delta Systems.

Ahn, R. (2010). Developing adult learners in a preservice teacher learning community. Educational Leadership and Administration: Teaching and Program Development, 22, $31-45$.

Alfaro, C. (2008). Global student teaching experiences: Stories bridging cultural and intercultural differences. Multicultural Education, 15(4), 20-26.

Amaro-Jiménez, C. (2016). Preservice teachers' reflections of their involvement in a homeschool connection project in teacher education. Bilingual Research Journal, 39(1), 69-85. doi: $10.1080 / 15235882.2016 .1139520$

Anderson, L. M., \& Stillman, J. A. (2013). Student teaching's contribution to preservice teacher development: A review of research focused on the preparation of teachers for urban and high-needs contexts. Review of Educational Research, 83(1), 3-69. doi:10.3102/0034654312468619

Arreguín-Anderson, M. G., \& Garza, E. V. (2014). Bilingual pairs in teacher education: Exploring wild strategies in an environmental education workshop. Action in Teacher Education, 36(2), 171-184. doi:10.1080/01626620.2014.898599

Athanases, S. Z., Banes, L. C., \& Wong, J. W. (2015). Diverse language profiles: Leveraging resources of potential bilingual teachers of color. Bilingual Research Journal, 38(1), 6587. doi:10.1080/15235882.2015.1017622

Athanases, S. Z., \& de Oliveira, L. C. (2007). Toward program-wide coherence in preparing teachers to teach and advocate for English language learners. In T. Lucas (Ed.), Teacher preparation for linguistically diverse classrooms (pp. 195-215). New York: Routledge.

Athanases, S. Z., \& Martin, K. J. (2006). Learning to advocate for educational equity in a teacher credential program. Teaching and Teacher Education, 22(6), 627-646. doi:10.1016/j.tate.2006.03.008

Athanases, S. Z., Wahleithner, J. M., \& Bennett, L. H. (2013). Learning about English learners' content understandings through teacher inquiry: Focus on writing. The New Educator, 9(4), 304-327. doi:10.1080/1547688X.2013.841506

Baecher, L., Schieble, M., Rosalia, C. \& Rorimer, S. (2013). Blogging for academic purposes with English language learners: An online fieldwork initiative. Contemporary Issues in Technology and Teacher Education, 13(1), 1-21.

Ballantyne, K. G., Sanderman, A. R., \& Levy, J. (2008). Educating English language learners: Building teacher capacity. Washington, DC: National Clearinghouse for English Language Acquisition.

Bartolomé, L. (1994). Beyond the methods fetish: Toward a humanizing pedagogy. The Harvard Educational Review, 64(2), 173-195. 
Block, D. (2002). Destabilized identities and cosmopolitanism across language and cultural borders: Two case studies. Hong Kong Journal of Applied Linguistics, 7(2), 1-19.

Bollin, G. G. (2007). Preparing teachers for Hispanic immigrant children: A service learning approach. Journal of Latinos and Education, 6(2), 177-189. doi:10.1080/15348430701305028

Bunch, G. (2013). Pedagogical language knowledge: Preparing mainstream teachers for English learners in the new standards era. Review of Research in Education, 37, 298-341. doi:10.3102/0091732X12461772

Bunten, B. (2010). "Welcome to America, now speak English": Preservice teachers' discourses focus on native Russian-speaking students. Multicultural Education, 17(4), 2-9.

Canagarajah, S. (2015). TESOL as a professional community: A half-century of pedagogy, research, and theory. TESOL Quarterly, 50(1), 7-41. doi:10.1002/tesq.275

Chamot, A., \& O’Malley, J. (1994). The CALLA handbook: Implementing the cognitive academic language learning approach. Reading, MA: Addison-Wesley.

Cho, J., Rios, F., Trent, A., \& Mayfield, K. (2012). Integrating language diversity into teacher education curricula in a rural context: Candidates' developmental perspectives and understandings. Teacher Education Quarterly, 39(2), 63-85.

Clark-Goff, K., \& Eslami, Z. (2016). Exploring change in preservice teachers' beliefs about English language learning and teaching. Iranian Journal of Language Teaching Research, 4(3), 21-36.

Cochran-Smith, M., Villegas, A., Abrams, L., Chavez-Moreno, L., Mills, T., \& Stern, R. (2015). Critiquing teacher preparation research: An overview of the field, Part II. Journal of Teacher Education, 66(2), 109-121.

Cole, M. and Engeström, Y. (1993) A cultural-historical approach to distributed cognition, in: G. Salomon (Ed.), Distributed cognitions: Psychological and educational considerations (New York, Cambridge University Press), 1-46.

Colón-Muñiz, A., SooHoo, S., \& Brignoni, E. (2010). Language, culture and dissonance: a study course for globally minded teachers with possibilities for catalytic transformation. Teaching Education, 21(1), 61-74. doi:10.1080/10476210903466976

Crawford, J., \& Adelman Reyes, S. (2015). The trouble with SIOP: How a behaviorist framework, flawed research, and clever marketing have come to define - and diminish - sheltered instruction. Portland, OR: Institute for Language and Education Policy.

Cummins, J. (2000). Language, power, and pedagogy: Bilingual children in the crossfire. Clevedon, England: Multilingual Matters.

Cummins, J. (2008). BICS and CALP: Empirical and theoretical status of the distinction. In B. Street \& N. H. Hornberger (Eds.), Encyclopedia of language and education: Volume 2. Literacy, 2nd ed. (pp. 71-83). New York, NY: Springer Science + Business Media.

Daniel, S. M. (2014) Learning to educate English language learners in pre-service elementary practicums. Teacher Education Quarterly, 41(2), 5-28. 
Dantas-Whitney, M., \& Waldschmidt, E. (2009). Moving toward critical cultural consciousness in ESOL and bilingual teacher education. Bilingual Research Journal, 32(1), 60-76. doi:10.1080/15235880902965888

Davin, K. J., \& Heineke, A. J. (2016). Preparing teachers for language assessment: A practicebased approach. TESOL Journal, 7(4), 921-938.

de Oliveira, L. C. (2011). In their shoes: Teachers experience the needs of English language learners through a math simulation. Multicultural Education, 19(1), 59-62.

de Oliveira, L. C., \& Athanases, S. Z. (2007). Graduates' reports of advocating for English language learners. Journal of Teacher Education, 58(3), 202-215.

Desimone, L. M. (2009). Improving Impact Studies of Teachers' Professional Development: Toward Better Conceptualizations and Measures. Educational Researcher, 38(3), 181199. https://doi.org/10.3102/0013189X08331140

DiCerbo, P., Anstrom, K., Baker, L., \& Rivera, C. (2014). A review of the literature on teaching academic English to English language learners. Review of Educational Research, 84, 446-482. doi:10.3102/0034654314532695

Dong, Y. R. (2004). Preparing secondary subject area teachers to teach linguistically and culturally diverse students. The Clearing House, 77, 202-208. doi:10.3200/TCHS.77.5.202-208

Dresser, R. (2007). The effects of teacher inquiry in the bilingual language arts classroom. Teacher Education Quarterly, 34, 53-66. Retrieved from http://files.eric.ed.gov/fulltext/EJ795172.pdf

Echeverria, J., Vogt, M., \& Short, D. (2003). Making content comprehensible for English Language Learners: The SIOP Model. New York: Pearson.

Ellis, V., Edwards, A., \& Smagorinsky, P. (2010). Cultural-historical perspectives on teacher education and development. Learning teaching. New York: Routledge.

Engeström, Y. (1987). Learning by expanding: an activity-theoretical approach to developmental research. Helsinki: Orienta-Konsultitz.

Engeström, Y. (2001). Expansive learning at work: Toward an activity theoretical reconceptualization. Journal of Education and Work, 14(1), 133-156.

Engeström, Y. (2007). Putting Vygotsky to work: The Change Laboratory as an application of double stimulation. In H. Daniels, M. Cole \& J. V. Wertsch (Eds.), The Cambridge companion to Vygotsky. Cambridge: Cambridge University Press.

Engeström, Y. (2008). From teams to knots: Activity-theoretical studies of collaboration and learning at work. Cambridge: Cambridge University Press.

Eros, J. (2016). "Give me a break--English is not my first language!": Experiences of linguistically diverse student teachers. Journal of Music Teacher Education, 26(1), 69-81.

Feiman-Nemser, S. (2001). From preparation to practice: Designing a continuum to strengthen and sustain teaching. Teachers College Record, 103(6), 1013-1055.

Fitts, S., \& Gross, L. (2012). Teacher candidates learning from English learners: Constructing concepts of language and culture in Tuesday's Tutors after-school program. Teacher Education Quarterly, 39(4), 75-95. 
Gadamer, H. (2012) Truth and Method (2nd ed.). London: Continuum.

Galguera, T. (2011). Participant structures as professional learning tasks and the development of pedagogical language knowledge among preservice teachers. Teacher Education Quarterly, 38(1), 85-106.

García, O., Johnson, S. I., \& Seltzer, K. (2017). The translanguaging classroom: Leveraging student bilingualism for learning. Philadelphia: Caslon.

Gebhard, M. (2010). Teacher education in changing times: A systemic functional linguistics (SFL) perspective. TESOL Quarterly, 44(4), 797-803.

Gibbons, P. (2002). Scaffolding language, scaffolding learning: Teaching second language learners in the mainstream classroom. Portsmouth, NH: Heinemann.

Gomez, S., Strage, A., Knutson-Miller, K., \& Garcia-Nevarez, A. (2009). Meeting the need for K-8 teachers for classrooms with culturally and linguistically diverse students: The promise and challenge of early field experiences. Teacher Education Quarterly, 36(4), 119-140.

Goldenberg, C. (2013). Unlocking the research on English Learners: What we know and don't know yet about effective instruction. American Educator, Summer, 4-11.

Gunn, A. A., Peterson, B. J., \& Welsh, J. L. (2015). Designing teaching cases that integrate course content and diversity issues. Teacher Education Quarterly, 42(1), 67-81.

Gutiérrez, K., Baquedano-Lopez, P., \& Tejada, C. (1999). Rethinking diversity: Hybridity and hybrid language practices in the third space. Mind, Culture, and Activity, 6(4), 286-303.

Hale, A. (2008). Service learning with Latino communities: Effects on preservice teachers. Journal of Hispanic Higher Education, 7(1), 54-69. doi:10.1177/1538192707310511

Halliday, M. A. K. (1993). Towards a language-based theory of learning. Linguistics and Education, 5(2), 93-116. doi:10.1016/0898-5898(93)90026-7

Halliday, M. A. K. (1994). An introduction to functional grammar. London: Edward Arnold.

He, Y. (2013). Developing teachers' cultural competence: Application of Appreciative Inquiry in ESL teacher education. Teacher Development, 17(1), 55-71. doi:10.1080/13664530.2012.753944

Heritage, M., Walqui, A., \& Linquanti, R. (2015). English language learners and the new standards: Developing language, content knowledge, and analytical practices in the classroom. Cambridge, MA: Harvard University Press.

Hooks, L. (2008) Help! They don't speak English: Partnering preservice teachers with adult English language learners. Journal of Early Childhood Teacher Education, 29(2), $97-$ 107. doi:10.1080/10901020802059433

Hsu, H. (2009). Preparing teachers to teach literacy in responsive ways that capitalize on students' cultural and linguistic backgrounds through weblog technology. Multicultural Education \& Technology Journal, 3(3), 168-181. doi:10.1108/17504970910984853

Hutchinson, M. (2013). Bridging the gap: Preservice teachers and their knowledge of working with English language learners. TESOL Journal, 4(1), 25-54. doi:10.1002/tesj.51 
Jahreie, C., \& Ottensen, E. (2010). Breaking out of a professional abstraction: the pupil as materialized object for trainee teachers. In V. Ellis, A. Edwards, \& P. Smagorinsky, Cultural-historical perspectives on teacher education and development. Learning teaching (pp. 131-145). New York: Routledge.

Janzen, J. (2008). Teaching English language learners in the content areas. Review of Educational Research, 78(4), 1010-1038. doi:10.3102/0034654308325580

Jimenez-Silva, M., \& Olson, K. (2012). A community of practice in teacher education: Insights and perceptions. International Journal of Sustainability in Higher Education, 24(3), 335-348.

Jimenez-Silva, M., Olson, K., \& Hernandez, N. (2012). The confidence to teach English language learners: Exploring coursework's role in developing preservice teachers' efficacy. Teacher Educator, 47(1), 9-28. doi:10.1080/08878730.2011.632471

Jurchan, J., \& Morano, T. A. (2010). The case study: Bringing real-world experience into the teacher preparation program. TESOL Journal, 1(1), 71-84. doi:10.5054/tj.2010.214880

Kasun, G. S., \& Saavedra, C. M. (2016). Disrupting ELL teacher candidates' identities: Indigenizing teacher education in one study abroad program. TESOL Journal 50(3), 684707.

Kayi-Aydar, H. (2015). Teacher agency, positioning, and English language learners: Voices of pre-service classroom teachers. Teaching and Teacher Education, 45,94-103.

Kelly-Jackson, C., \& Delacruz, S. (2014). Using visual literacy to teach science academic language: Experiences from three preservice teachers. Action in Teacher Education, 36(3), 192-210. doi:10.1080/01626620.2014.917364

Kibler, A. K., \& Roman, D. (2013). Insights into professional development for teachers of English language learners: A focus on using students' native languages in the classroom. Bilingual Research Journal, 36(2), 187-207.

Kim, Y. K., Hutchison, L. A., \& Winsler, A. (2015). Bilingual education in the United States: an historical overview and examination of two-way immersion. Educational Review, 67(2), 236-252.

Knight, S. L., Lloyd, G. M., Arbaugh, F., Gamson, D., McDonald, S. P., Nolan, J., \& Whitney, A. E. (2015). Reconceptualizing teacher quality to inform preservice and inservice Professional development. Journal of Teacher Education, Vol. 66(2), pp. 105-108.

Krashen, S. D. (2003). Explorations in language acquisition and use. Portsmouth, NH: Heinemann.

Konkola, R., Tuomi-Gröhn, T., Lambert, P., \& Ludvigsen, S. (2004). Developmental tools for promoting learning and transfer between school and workplace. Center for Activity Theory and Developmental Work Research, University of Helsinki.

Ladson-Billings, G. J. (1999). Chapter 7: Preparing Teachers for Diverse Student Populations: A Critical Race Theory Perspective. Review of Research in Education, 24(1), 211-247. https://doi.org/10.3102/0091732X024001211

Leontiev, A. A. (1981). Psychology and the language learning process. Oxford: Pergamon. 
Liu, Y., \& Fisher, L. (2010). 'What have we learnt after we had fun': An activity theory perspective on the cultures of learning in pedagogical reforms. In V. Ellis, A. Edwards \& P. Smagorinsky (Eds.), Cultural-historical perspectives on teacher education and development: Learning teaching (pp. 180-195). Oxon: Routledge/Taylor and Francis.

Lucas, T. \& Villegas, A. (2011). A framework for preparing linguistically responsive teachers. In T. Lucas (Ed.), Teacher preparation for linguistically diverse classrooms: A resource for teacher educators (pp. 55-73). New York: Routledge.

Lucas, T., \& Villegas, A. (2013). Preparing linguistically responsive teachers: Laying the foundation in preservice teacher education. Theory Into Practice, 52(2), 98-109. doi:10.1080/00405841.2013.770327

Lyon, E. G. (2013). Learning to assess science in linguistically diverse classrooms: Tracking growth in secondary science preservice teachers' assessment expertise. Science Education, 97(3), 442-4678. doi:10.1002/sce.21059

Lysaker, J., \& Thompson, B. (2013). Teacher research as a practical tool for learning to teach. Language Arts, 90(3), 181-191.

MacQueen, K. M., McClellan-Lemal, E., Bartholow, K., \& Milstein, B. (2007). Team-based codebook development: Structure, process, and alignment. In G. Guest \& K. M. MacQueen (Eds.), Handbook for team-based qualitative research (pp. 119-135). New York: Altamira Press.

Major, E. M., \& Perreault, G. (2004). Preparing teachers for social consciousness: Issues of engagement and resistance. Teacher Education and Practice, 17(3), 255-278.

Markos, A. (2012). Mandated to learn, guided to reflect: Pre-service teachers' evolving understanding of English language learners. Issues in Teacher Education, 21(1), 39-57.

Marx, S. (2004). Regarding whiteness: Exploring and intervening in the effects of white racism in teacher education. Equity and Excellence in Education, 37(1), 31-43. doi:10.1080/10665680490422089

Martin, A. D., \& Strom, K. J. (2016). Toward a Linguistically Responsive Teacher Identity: An Empirical Review of the Literature. International Multilingual Research Journal, 10(4), 239-253. https://doi.org/10.1080/19313152.2016.1189799

Master, B., Loeb, S., Whitney, C., \& Wyckoff, J. (2016). Different skills?: Identifying differentially effective teachers of English language learners. The Elementary School Journal, 117(2), 261-284.

Max, C. (2010). Learning-for-teaching across educational boundaries: An activitytheoretical analysis of collaborative internship projects in initial teacher education. Cultural historical perspectives on teacher education and development: learning teaching. Learning teaching, 212-240.

McDonald, M. A. (2005). The integration of social justice in teacher education: Dimensions of prospective teachers' opportunities to learn. Journal of Teacher Education, 56(5), 418435. 
McNess, E., Arthur, L. \& Crossley, M. (2015). 'Ethnographic dazzle' and the Construction of the 'Other': revisiting dimensions of insider and outsider research for international and comparative education. Compare, 45(2), 295-316. doi:10.1080/03057925.2013.854616

Medina, A. L., Hathaway, J. I., \& Pilonieta, P. (2015). How preservice teachers' study abroad experiences lead to changes in their perceptions of English language learners. Frontiers: The Interdisciplinary Journal of Study Abroad, 25, 73-90.

Menken, K. (2010). English learners left behind: Standardized testing as language policy. Clevedon, England: Multilingual Matters.

Miles, M. B., \& Huberman, A. M. (1994). Qualitative data analysis (2nd ed.). Thousand Oaks, CA: Sage.

Miller, K. (2017). "El pasado refleja el futuro": Pre-service teachers' memories of growing up bilingual. Bilingual Research Journal, 40(1), 20-37, doi:10.1080/15235882.2016.1276031

Moll, L. C., Amanti, C., Neff, D., \& González, N. (1992). Funds of knowledge for teaching: Using a qualitative approach to connect homes and classrooms. Theory into Practice, 31(1), 132-141. doi:10.1080/00405849209543534

Motha, S. (2014). Race, empire, and English language teaching: Creating responsible and ethical anti-racist practice. New York: Teachers College Press.

Musanti, S. I., \& Rodríguez, A. D. (2017). Translanguaging in bilingual teacher preparation: Exploring pre-service bilingual teachers' academic writing. Bilingual Research Journal, 40(1), 38-54.

Nichols, J. D., \& Soe, K. (2013). An analysis of preservice teacher responses to participation in a literacy program for new immigrant children. Multicultural Perspectives, 15(4), 220-226. doi:10.1080/15210960.2013.844609

Nieto, S., \& Bode, P. (2012). Affirming diversity: The sociopolitical context of multicultural education (6th ed.). Boston, MA: Pearson.

Olson, K., \& Jimenez-Silva, M. (2008). The campfire effect: A preliminary analysis of preservice teachers' beliefs about teaching English language learners after state-mandated endorsement courses. Journal of Research in Childhood Education, 22(3), 246-260. doi:10.1080/02568540809594625

Orellana, M. F., \& Reynolds, J. (2008). Cultural modeling: Leveraging bilingual skills for school paraphrasing tasks. Reading Research Quarterly, 43, 48-65.

Otaiba, S. A. (2005). How effective is code-based reading tutoring in English for English learners and preservice teacher-tutors? Remedial and Special Education, 26(4), 245-254. doi:10.1177/07419325050260040701

Ovando, C. J. (2003). Bilingual Education in the United States: Historical Development and Current Issues. Bilingual Research Journal, 27(1), 1-24. https://doi.org/10.1080/15235882.2003.10162589

Pappamihiel, E. (2004). Hugs and smiles: Demonstrating caring in a multicultural early childhood classroom. Early Child Development and Care, 174(6), 539-548. doi:10.1080/0300443042000187059 
Pappamihiel, E. (2007). Helping preservice content-area teachers relate to English language learners: An investigation of attitudes and beliefs. TESL Canada Journal, 24(2), 42-60. doi:10.18806/tesl.v24i2.138

Pettit, S. K. (2011). Teachers' beliefs About English language learners in the mainstream classroom: A review of the literature. International Multilingual Research Journal, 5(2), 123-147. doi:10.1080/19313152.2011.594357

Pilonieta, P., Medina, A. L., \& Hathaway, J. I. (2017). The impact of a study abroad experience on preservice teachers' dispositions and plans for teaching English language learners. The Teacher Educator, 52(), 22-38. doi:10.1080/08878730.2016.1247204

Ramirez, P. C., Gonzales-Galindo, D., \& Roy, B. (2016). Preparing pre-service secondary teachers in Arizona: Using culturally responsive approaches to learn from diverse secondary English learners. Multicultural Education, 23(2), 22-30.

Reece, L., \& Nodine, P. (2014). When immigrant is synonymous with terrorist: Culturally responsive teaching with English learners. The Social Studies, 105(6), 259-265. doi:10.1080/00377996.2014.93040

Reeves, J. (2004). "Like everybody else": Equalizing educational opportunity for English language learners. TESOL Quarterly, 38(1), 43-66. doi:10.2307/3588258

Regalla, M. (2016). Getting out of their comfort zone: Examining teacher candidates' reactions to service-learning abroad. Multicultural Perspectives, 18(2), 65-72, doi:10.1080/15210960.2016.1152893

Regalla, M., Hutchinson, C., Nutta, J. \& Ashtari, N. (2016). Examining the impact of simulation classroom experience on teacher candidates' sense of efficacy in communicating with English learners. Journal of Technology and Teacher Education, 24(3), 337-367.

Risko, V. J., \& Walker-Dalhouse, D. (2007). Tapping students' cultural funds of knowledge to address the achievement gap. The Reading Teacher, 61(1), 98-100.

Rodriguez, T. L., \& Polat, N. (2012). Politicizing difference: Interpreting citizenship as a dimension of diversity in pre-service teachers' narratives. Linguistics and Education, 23, 361-372. doi:10.1016/j.linged.2012.08.001

Ruiz, N. T., Baird, P. J., \& Hernández, P. T. (2016). Field practice in La Mixteca: Transnational teacher education in the service of Mexican indigenous students in U.S. schools. Journal of Latinos and Education, 15(2), 97-112, doi:10.1080/15348431.2015.1066256

Salerno, A. S., \& Kibler, A. K. (2013). Before they teach: How pre-service teachers plan for linguistically diverse students. Teacher Education Quarterly, 40(4), 5-26.

Samson, J. F. \& Collins, B. A. (2012). Preparing all teachers to meet the needs of English language learners. Washington DC: Center for American Progress.

Santamaría, L. J., Santamaría, C. C., \& Fletcher, T. V. (2009). Journeys in cultural competency: Pre-service U.S. teachers in Mexico study-abroad programs. Diaspora, Indigenous, and Minority Education, 3(1), 32-51. doi:10.1080/15595690802584166

Samson, J. F. \& Collins, B. A. (2012). Preparing all teachers to meet the needs of English language learners. Washington DC: Center for American Progress. 
Schall-Leckrone, L, \& McQuillan, P. J. (2012). Preparing history teachers to work with English learners through a focus on the academic language of historical analysis. Journal of English for Academic Purposes, 11(3), 246-266. doi:10.1016/j.jeap.2012.05.001

Schleppegrell, M. J. (2004). The language of schooling: A functional linguistics perspective. Mahwah, NJ: Lawrence Erlbaum.

Schleppegrell, M., \& Achugar, M. (2003). Learning language and learning history: A functional linguistics approach. TESOL Journal, 12(2), 21-27.

Schleppegrell, M. J., Achugar, M. \& Oteíza, T. (2004). The grammar of history: Enhancing content-based instruction through a functional focus on language. TESOL Quarterly, $38(1), 67-93$.

Siegel, M. (2013). Developing preservice teachers' expertise in equitable assessment for English learners. Journal of Science Teacher Education, 25(3), 289-308. doi:10.1007/s10972-013-9365-9

Sleeter, C. (2014). Toward teacher education research that informs policy. Educational Researcher, 43(3), 146-153 doi:10.3102/0013189X14528752

Stoddard, T., Solis, J., Lyon, E. G., \& Tolbert, S. (2016). Preparing pre-service secondary teachers to teach science to English learners: Theory into practice. In A. W. Oliveira \& M. H. Weinburgh (Eds.), Science teacher preparation in content-based second language acquisition (pp. 97-115). Switzerland: Springer International Publishing.

Teemant, A., \& Hausman, C. S. (2013). The relationship of teacher use of critical sociocultural practices with student achievement. Critical Education, 4(4), 1-20.

Thomas, W. P., \& Collier, V. P. (2002). A national study of school effectiveness for language minority students' long-term academic achievement. Santa Cruz, CA: Center for Research on Education, Diversity and Excellence, University of California-Santa Cruz.

Thorpe, R. \& Holt, R. (2008). The SAGE dictionary of qualitative management research. London: SAGE Publications Ltd. doi: 10.4135/9780857020109

Turkan, S., de Oliveira, L., Lee, O., Phelps, G. (2014). Proposing a knowledge base for teaching academic content to English language learners: Disciplinary linguistic knowledge. Teachers College Record, 116(3), 1-30.

Turner, E., \& Drake, C. (2016). A review of research on prospective teachers' learning about children's mathematical thinking and cultural funds of knowledge. Journal of Teacher Education, 67(1), 32-46.

U.S. Census Bureau. (n.d.). Census regions and divisions of the United States. Retrieved From http://www2.census.gov/geo/pdfs/maps-data/maps/reference/us_regdiv.pdf

Uzum, B., Petron, M., \& Berg, H. (2014). Pre-service teachers' first foray into the ESL classroom: Reflective practice in a service learning project. TESL-EJ, 18(3), 1-15.

Valenzuela, A. (1999). Subtractive schooling: U.S.-Mexican youth and the politics of caring. Albany, NY: SUNY Press.

Vavrus, F. \& Bartlett, L. (2017). Rethinking case study research: A comparative approach. New York: Routledge. 
Virtue, D. C. (2009). Using "ESOL rounds" to prepare middle level candidates for work with English language learners. Middle Grades Research Journal, 4(1), 1-24.

Wade, S.E., Fauske, J.R., \& Thompson, A. (2008). Prospective teachers' problem solving in online peer-led dialogues. American Educational Research Journal, 45(2), 398-442. doi:10.3102/0002831207308224

Walker-Dalhouse, D., Sanders, V., \& Dalhouse, A. (2009). A university and middle-school partnership: Preservice teachers' attitudes toward ELL students. Literacy Research and Instruction, 48(4), 337-349. doi:10.1080/19388070802422423

Walqui, A. (2007). The development of teacher expertise to work with adolescent English learners: A model and a few priorities. In L. S. Verplaetse \& N. Migliacci (Eds.), Inclusive pedagogy for English language learners: A handbook of research-informed practices (pp. 103-125). New York, NY: Lawrence Erlbaum.

Warren, S. R., Reeder, G. M., Noftle, J. T., Kaiser, G. J., \& Jurchan-Rizzo, J. (2010). Preparing teachers to support English language learners. TESOL Journal, 1(3), 291-314. doi:10.5054/tj.2010.226826

Wong, P. (2008). Transactions, transformation, and transcendence: multicultural servicelearning experience of preservice teachers. Multicultural Education, 16(2), 31-36.

Wright, W. E., Boun, S. \& García, O. (2015). Introduction: Key concepts and issues in bilingual and multilingual education. In W. E. Wright, S. Boun, \& O. García (Eds.), Handbook of Bilingual and Multilingual Education (pp. 1-16). Malden, MA: WileyBlackwell.

Wright-Maley \& Green (2015). Experiencing the needs and challenges of ELLs: Improving knowledge and efficacy of pre-service teachers through the use of a language immersion simulation. Cogent Education, 2(1), 1-17.

Wu, H-P., \& Guerra, M. J. (2017). Examination of pre-service teacher's training through tutoring approach. Journal of Education and Training Studies, 5(2), 1-9.

Vygotsky, L. S. (1978). Mind in society: The development of higher psychological processes. Cambridge, MA: Harvard University Press.

Yamagata-Lynch, L. C. (2010). Activity systems analysis methods for understanding complex learning environments. New York: Springer.

Zainuddin, H., \& Moore, R. A. (2004). Engaging preservice teachers in action research to enhance awareness of second language learning and teaching. Teacher Education and Practice, 17(3), 311-327.

Zhang, J., \& Pelttari, C. (2014). Exploring the emotions and needs of English language learners: Facilitating pre-service and in-service teachers' recognition of the tasks facing language learners. Journal of Multilingual and Multicultural Development, 35(2), 179-194. doi:10.1080/01434632.2013.822505

Zhang, S., \& Stephens, V. (2013). Learning to teach English-language learners in mainstreamed secondary classrooms. Teacher Education and Practice, 26(1), 99-116. 
Table 1

Linguistically Responsive Teaching Framework

\section{Orientations \\ Pedagogical Knowledge and Skills}

Sociolinguistic consciousness

A repertoire of strategies for learning about the linguistic and academic backgrounds of ELLs in English and their native languages

Value for language diversity

An understanding of and ability to apply key principles of second language learning

Inclination to advocate for English language learners

Ability to identify the language demands of classroom tasks

A repertoire of strategies for scaffolding instruction for ELLs 
Table 2

Articles Included in the Literature Review, by Activity System

\begin{tabular}{|c|c|c|}
\hline Orientations (n=36) & Pedagogical Knowledge and Skills $(\mathrm{n}=12)$ & Combination $(\mathrm{n}=16)$ \\
\hline Arreguin-Anderson \& Garza (2014) & Athanases, Wahleithner, \& Bennet (2013) & Ahn (2010) \\
\hline Athanases, Banes, \& Wong (2015) & Baecher, Schieble, Rosalia, \& Rorimer (2013) & Amaro-Jimenez (2016) \\
\hline Bollin (2007) & Bunten (2010) & Athanases \& Martin (2006) \\
\hline Cho, Rios, Trent, \& Mayfield (2012) & Dong (2004) & Dantas-Whitney \& Waldschmidt (2009) \\
\hline Clark-Goff \& Eslami (2016) & Dresser (2007) & Davin \& Heineke (2016) \\
\hline Colon-Muniz, SooHoo, \& Brignoni (2010) & Jimenez-Silva, Olson, \& Hernandez (2012) & Jurchan \& Murano (2011) \\
\hline Daniel (2014) & Kelly-Jackson \& Delacruz (2014) & Lysaker \& Thompson (2013) \\
\hline de Oliveira (2011) & Lyon (2013) & Olson \& Jimenez-Silva (2008) \\
\hline Eros (2016) & Schall-Leckrone \& McQuillan (2012) & Ramirez, Gonzales-Galindo, \& Roy (2016) \\
\hline Fitts \& Gross (2012) & Stoddard, Solis, Lyon, \& Tolbert (2016) & Ruiz, Baird, \& Hernandez (2016) \\
\hline Gomez, Strage, Knutson-Miller, \& Garcia-Nevarez(2009) & Uzum, Petron, \& Berg (2014) & Salerno \& Kibler (2013) \\
\hline Gunn, Peterson, \& Welsh (2015) & Zhang \& Stephens (2013) & Siegel (2013) \\
\hline Hale (2008) & & Walker-Dalhouse, Sanders, \& Dalhouse (2009) \\
\hline Hooks (2008) & & Warren, Reeder, Noftle, Kaiser, \& Jurchan-Rizzo (2010) \\
\hline Hsu (2009) & & Wong (2008) \\
\hline Hutchinson (2013) & & Wu \& Guerra (2017) \\
\hline \multicolumn{3}{|l|}{ Jimenez-Silva \& Olson (2012) } \\
\hline \multicolumn{3}{|l|}{ Kasun \& Saavedra (2016) } \\
\hline \multicolumn{3}{|l|}{ Markos (2012) } \\
\hline \multicolumn{3}{|l|}{ Marx (2004) } \\
\hline \multicolumn{3}{|l|}{ Medina, Hathaway, \& Pilonieta (2015) } \\
\hline \multicolumn{3}{|l|}{ Miller (2017) } \\
\hline \multicolumn{3}{|l|}{ Nichols \& Soe (2013) } \\
\hline \multicolumn{3}{|l|}{ Otaiba (2005) } \\
\hline \multicolumn{3}{|l|}{ Pappamihiel (2004) } \\
\hline \multicolumn{3}{|l|}{ Pappamihiel (2007) } \\
\hline \multicolumn{3}{|l|}{ Pilonieta, Medina, \& Hathaway (2017) } \\
\hline \multicolumn{3}{|l|}{ Reece and Nodine (2014) } \\
\hline \multicolumn{3}{|l|}{ Regalla (2016) } \\
\hline \multicolumn{3}{|l|}{ Regalla, Hutchinson, Nutta, \& Ashtari (2016) } \\
\hline \multicolumn{3}{|l|}{ Rodriguez and Polat (2012) } \\
\hline \multicolumn{3}{|l|}{ Santamaria, Santamaria, \& Fletcher (2009) } \\
\hline \multicolumn{3}{|l|}{ Virtue (2009) } \\
\hline \multicolumn{3}{|l|}{ Wade, Fauske, \& Thompson (2008) } \\
\hline \multicolumn{3}{|l|}{ Wright-Maley \& Green (2015) } \\
\hline Zhang \& Pelttari (2014) & & \\
\hline
\end{tabular}


Figure 1

Activity Systems in Teacher Preparation

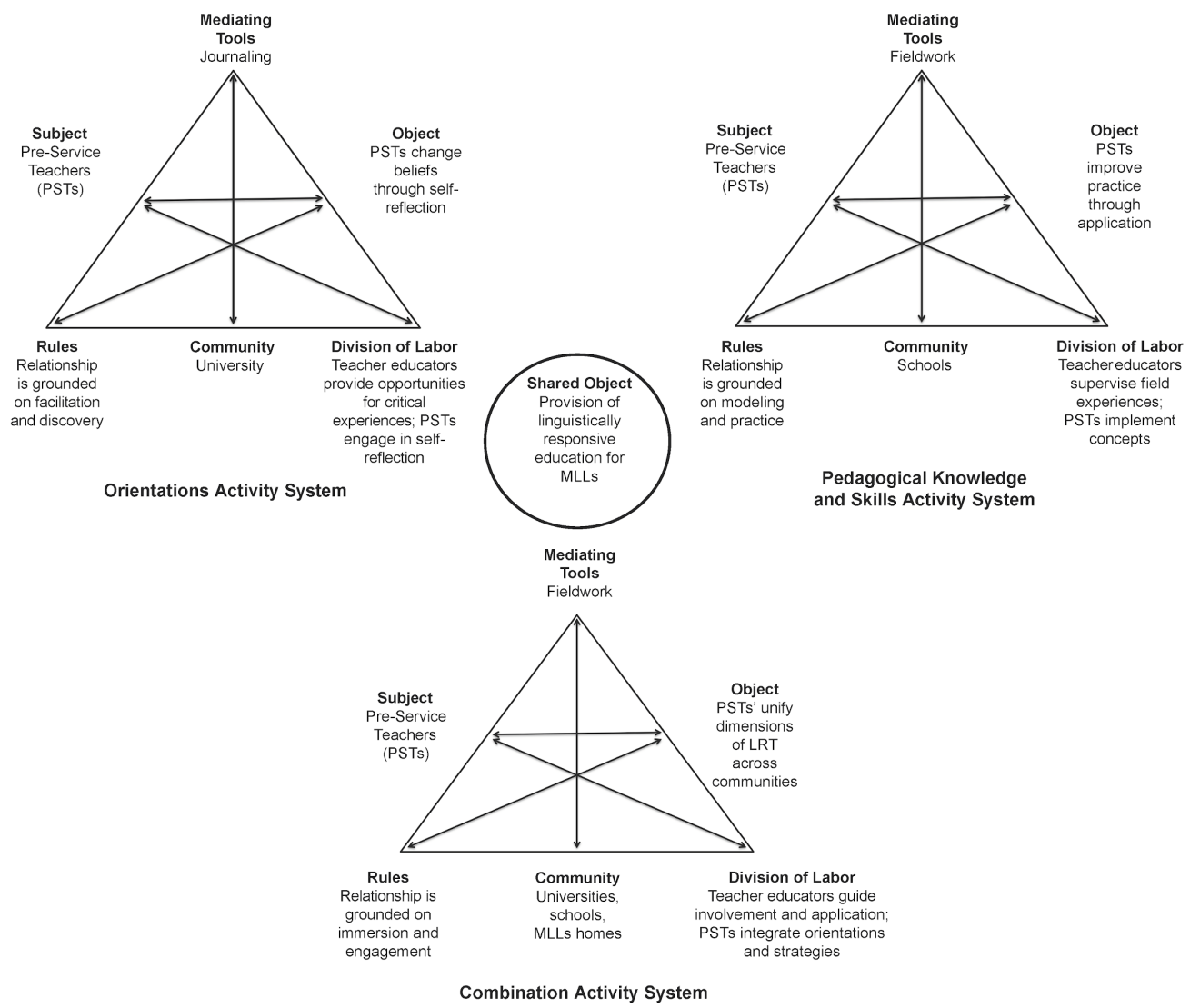

